\title{
Late Permian rifting of the South China Craton caused by the Emeishan mantle plume?
}

\author{
XIE-YAN SONG ${ }^{1,2}$, MEI-FU ZHOU ${ }^{1}$, ZHI-MIN CAO ${ }^{3}$ \& PAUL T. ROBINSON ${ }^{1}$ \\ 'Department of Earth Sciences, University of Hong Kong, Pokfulam Road, Hong Kong, China \\ (e-mail:xsong@hkusua.hku.hk) \\ ${ }^{2}$ Third Department, Chengdu University of Technology, Chengdu, China \\ ${ }^{3}$ College of Earth Sciences, Ocean University of Qingdao, Qingdao, China
}

\begin{abstract}
Stratigraphic relationships and bulk-rock geochemical data indicate that Upper Permian metabasalts in the Songpan-Ganzi and Yidun terrancs, on the eastern margin of the Tibetan Plateau, are part of the Emeishan large igneous province, which is belicved to have formed from the Emeishan mantle plume. Eruption of the Emeishan basalts at $260 \mathrm{Ma}$ was coincident with rifting of the western margin of the South China Craton to form the Songpan-Ganzi ocean basin. The spatial and temporal coincidence between basalt eruption and continental rifting, as well as regional doming prior to eruption, suggest that continental brak-up was a response to the Late Permian Emeishan plume. The Songpan-Ganzi ocean basin was rapidly filled with Triassic fysch deposits, then deformed and uplifted during Mesozoic collision between the North China and South China Blocks and the Tertiary collision of India and Eurasia.
\end{abstract}

Keywords: Songpan - Ganzi, South China Craton, Emeishan basalts, Tibet, mantle plumes.

The relationship between the Tibetan Plateau and the South China Craton, and the timing and mechanism of formation of the giant Songpan-..Ganzi Triassic Basin on the eastern edge of the Tibetan Plateau, have long been matters of debate (Sengor \& Natal'in 1996; Chang 2000). Likcwise, the role of the Permian Emeishan mantle plume in the tectonics of South China is not well understood.

The Songpan-Ganzi Basin is a huge triangular-shaped feature filled with Triassic marine flysch deposits that locally exceed $15 \mathrm{~km}$ in thickness (Bruguier \& Malavieille 1997). It has been interpreted as a remnant ocean basin (Sengor \& Natal'in 1996; Zhou \& Graham 1996) and as a Permian-Triassic rift basin formed at a triple junction (Chang 2000).

The Emeishan large igneous province covers an area of more than $500,000 \mathrm{~km}^{2}$ in the western part of the South China Craton (Zhou et al. 2002a). The geochemistry of the Emeishan continental flood basalts and their short eruption period of less than $1 \mathrm{Ma}$ in the Late Permian are consistent with mantle plume volcanism (Chung \& Jahn 1995; Song et al. 2001; Thompson et al. 2001; Ali et al. 2002; Zhou et al. 2002a). Similar metabasalts have been recognized in the Songpan-Ganzi and Yidun terranes on the eastern margin of the Tibetan Plateau (BGMS 1991; Song et al. 2003) (Fig. 1), but their relationship to the Emeishan continental flood basalts, $100-300 \mathrm{~km}$ to the east, has not been established. If these lavas are part of the Emeishan large igneous province, they place tight time constraints on rifting of the South China Craton and the formation of the Songpan--Ganzi ocean basin. Correlation of the metabasalts with the Emeishan lavas would also indicate that a huge volume of magma was erupted just prior to break-up of the western margin of the craton. The temporal and geographical coincidence of these two events implies that the Emeishan mantle plume was responsible for the break-up of the South China Craton and the formation of the Palaeo-Tethyan Songpan--Ganzi ocean basin.

The purpose of this paper is to test our proposed correlation of the Upper Permian metabasalts in the Songpan-Ganzi and Yidun terranes with the Emeishan basalts on the western South China Craton, and to investigate the role of the Emeishan plume in the tectonic evolution of the region.

\section{Geological background}

The eastern margin of the Tibetan Plateau is a complex geological zone about $200 \mathrm{~km}$ wide, composed of the Songpan Ganzi and Yidun terranes. Together, these two terranes make up a giant triangular block, bounded on the north by the Kunlun. Animaqing suture from the Kunlun orogenic belt (Mattauer et al. 1992; Yang et al. 1996), on the east by the Longmenshan lhrust belt from the South China Block (Burchficl et al. 1995; Bruguier \& Malavieille 1997), and on the west and SW by the Jinsha suture from the Qiangtang Terrane (Fig. 1).

The Songpan-Ganzi Terrane, with an area of more than $200000 \mathrm{~km}^{2}$, is characterized by a thick, strongly folded Triassic flysch sequence. This was derived from the Dabic Sulu orogenic belt, to the NE, and deposited in the Songpan Ganzi ocean basin (Yin \& Nie 1993; Yin \& Harrison 2000). In contrast, the NNWtrending Yidun Terrane contains mostly Lower Triassic clastic rocks and Middle-Upper Triassic calc-alkaline volcanic rocks produced by westward subduction of the Songpan Ganzi occan lithosphere (Fig. 1) (Hou et al. 2001). The Ganzi Litang suture, which separates these two terranes, extends from west of Canzi on the north through Litang to Muli on the south, a distance of over $1000 \mathrm{~km}$ (Fig. 1). Ophiolitic mélange, composed of serpentinite, gabbro, pillow basalt and chert, occurs as tectonic blocks in the Upper Triassic sedimentary rocks along this suture. The ophiolitic material was derived from the Songpan Ganzi ocean basin (Mo et al. 1993; Zhong 1998).

Neoproterozoic granitic gneisses and metavoleanic rocks in the southeastern margin of the Songpan-Canzi Terrane and the southern part of the Yidun Terrane are petrologically and geochemically comparable with Ncoproterozoic basement complexes in the western margin of the South China Craton (Zhou 

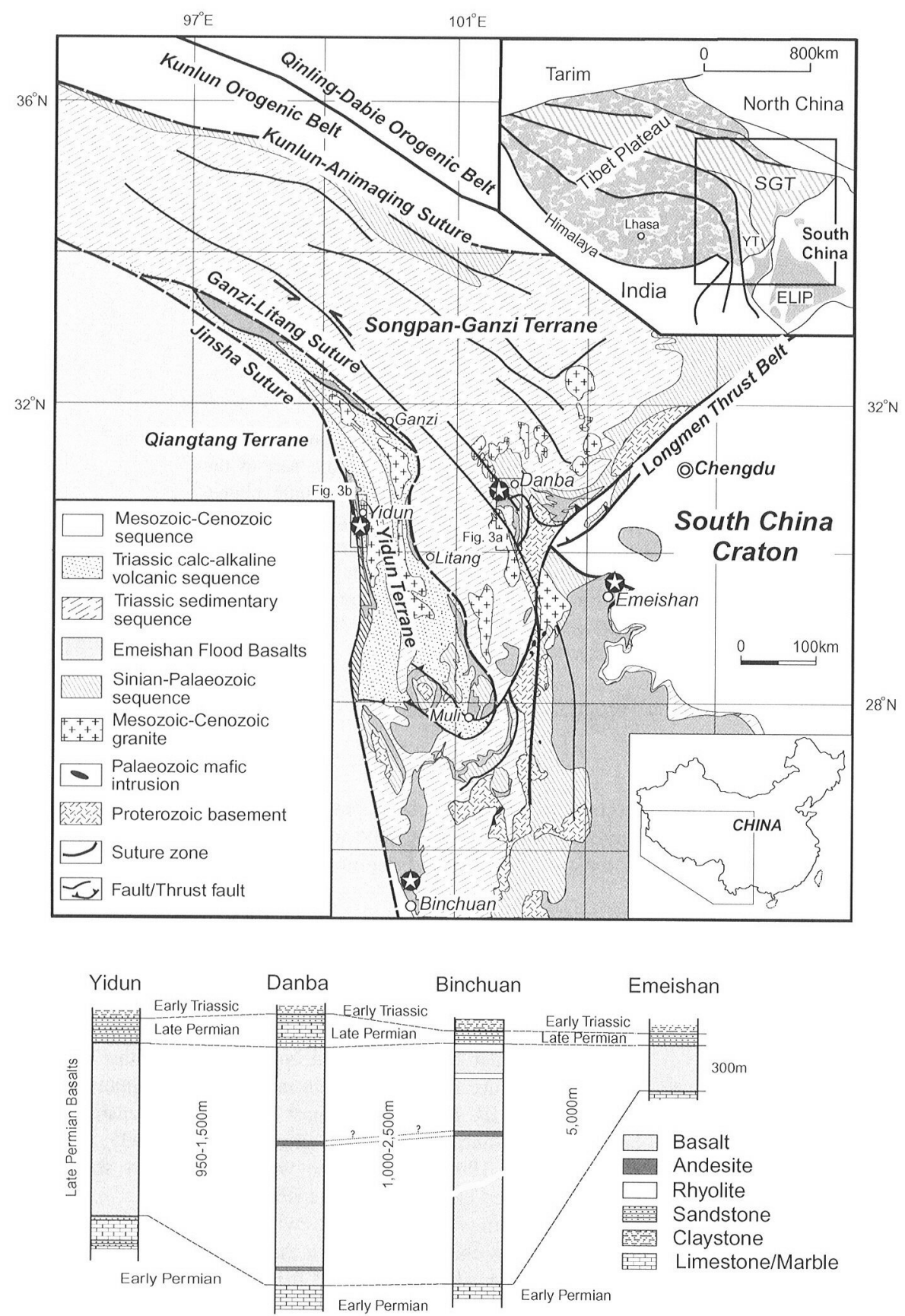

Fig. 1. Regional geological map of the Songpan-Ganzi and Yidun terranes, modified from the regional geological maps of Sichuan, Yunnan and Qinghai Provinces, China. SGT, Songpan-Ganzi Terrane; YT, Yidun Terrane; ELIP, Emeishan large igneous province. The Emeishan basalt column of Bichuan is modified after Huang et al. (1986), and the column at Emeishan is after Zhou et al. (2002a). Stars represent the locations of the columns.

et (al. 2002b). Thesc basement complexes are believed to have been formed in an arc setting above a subduction zone beneath the South China Craton at c. 760-860 Ma (Fig. 2) (Roger \& Calassou 1997; Zhou et al. 2002b).

Along the southeastern margin of the Songpan-Ganzi Terrane and in the southern Yidun Terrane, the Neoproterozoic rocks are unconformably overlain by thick Sinian-Lower Permian continental margin shallow- to decp-marine clastic and carbonate sedimentary rocks with a few volcanic intercalations (BGMS 1991; Chang 2000) (Fig. 2). These strata are lithologically similar to Sinian-Lower Pcrmian shallow-marine clastic sedimentary rocks and carbonates of the western part of the South China Craton (Fig. 2) (BGMS 1991). In addition, identical Ordovician to Lower Permian fossils occur in the sedimentary rocks of the three regions (Fig. 2) (BGMS 1991). Correlation of similar sedimentary sequences with the same fossils in these three tectonic blocks (BGMS 1991; Chang 2000; Yin \& Harrison 2000) (Fig. 1) indicates that they were contiguous at least until Late Permian time.

\section{Stratigraphy of the Upper Permian basalts}

In their type locality at Emeishan Mountain, the Emeishan continental flood basalts lie between Lower Permian limestone and Upper Permian sandstone and mudstone. A thin, weathered zone at the base of the Emeishan continental flood basalts implies uplift and cxposure of the limestone before eruption of the basalts. The Upper Permian sedimentary sequence on top of 
Songpan-Ganzi

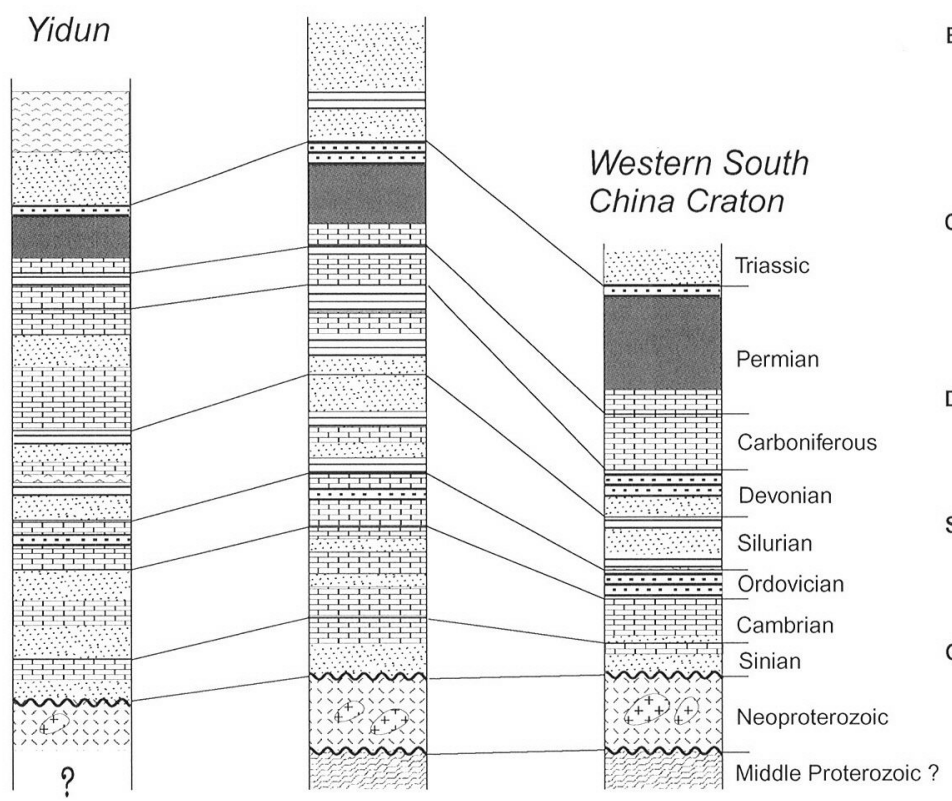

Common fossils

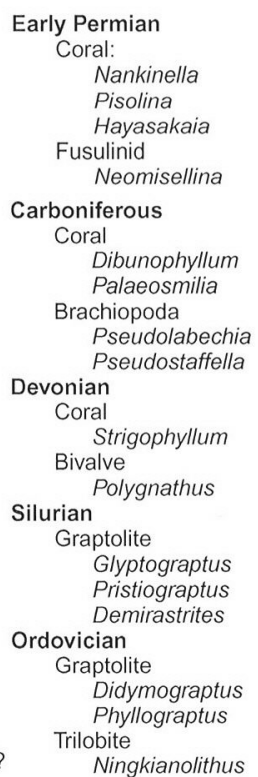

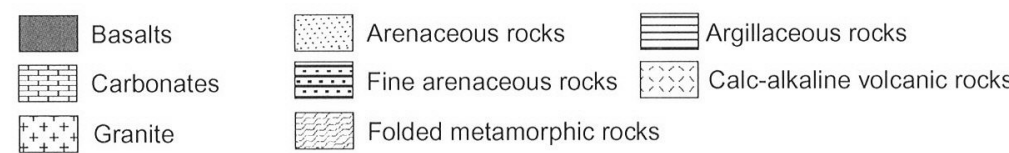

Fig. 2. Stratigraphic correlation of Proterozoic, Palaeozoic and Triassic rocks of the Songpan-Ganzi and Yidun terranes with those of the western margin of the South China Craton. Neoproterozoic calcalkaline volcanic rocks are unconformably overlain by Sinian to Lower Permian shallow- to deep-marine clastic rocks and carbonates in the three tectonic blocks. The Ordovician to Lower Permian fossils listed in the figure are common to all three blocks (BGMS 1991) the Emeishan continental flood basalts is, in turn, unconformably overlain by Triassic clastic rocks (Fig. 1). At Emeishan Mountain, the lavas consist dominantly of aphyric and plagioclasephyric basalt with columnar jointing.

As shown in Figs 1 and 3a, Upper Pcrmian metabasalts are exposed along thrust faults and around tectonic domes along the southeastern margin of the Songpan-Ganzi Terrane. In the Danba area, about $1500-2500 \mathrm{~m}$ of massive metabasalts disconformably overlie Lower Permian marble, which is equivalent to the Lower Permian limestone of the South China Craton, and are overlain by Uppermost Permian metasandstone, which in turn is conformably overlain by Triassic metasedimentary rocks.

In the Yidun Terrane, Upper Permian metabasaits are well exposed along major NNW-trending faults. In the western part of the terrane, a sequence of massive flows, several hundred metres to $1500 \mathrm{~m}$ thick, occurs in the Yidun area (Figs 1 and $3 \mathrm{~b}$ ). These basalts disconformably overlie Lower Permian marble containing fossil assemblages similar to those found in the Lower Pcrmian limestone of the South China Craton (BGMS 1991), and are overlain by Upper Permian marble and slate (Fig. 2). The Upper Permian rocks are, in turn, overlain by Lower Triassic clastic rocks.

Correlation of the sedimentary rocks above and below the metabasalts in the Songpan-Ganzi and Yidun terranes with those in the South China Craton demonstrates that the basalts in these three areas formed at the same time, strongly suggesting that they are all part of the Emeishan large igneous province.

\section{Analytical techniques}

Major oxides were determined using XRF spectrometry on fused glass discs at the University of Hong Kong. $\mathrm{Sc}, \mathrm{Ni}$ and $\mathrm{Cu}$ were determined by
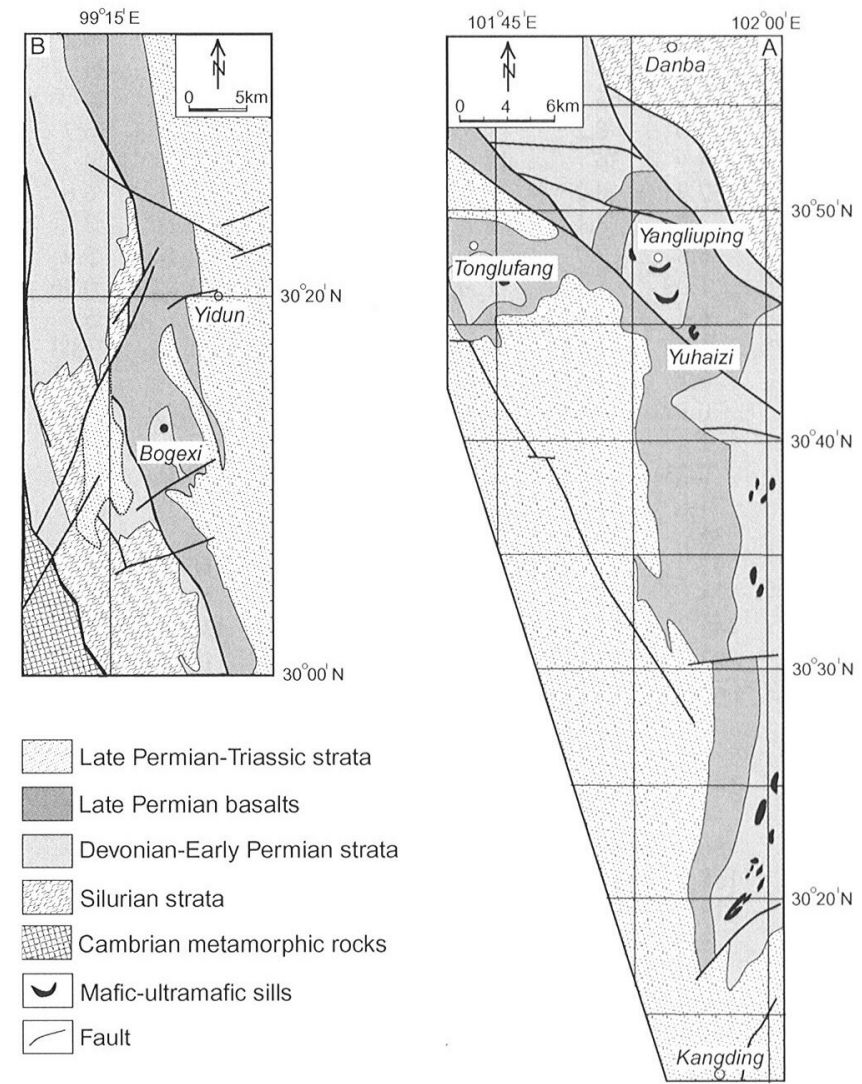

Fig. 3. (a) Distribution of Upper Permian basalts in the Danba area. (b) Distribution of Upper Permian basalts in the Yidun area. 
XRF on pressed powder pellets. Other trace elements, including REE, were analysed by inductively coupled plasma mass spectrometry (ICPMS) on a V(i Elemental PQ Excell system at the University of Hong Kong. We used standard additions, pure elemental standards for external calibration, and BHVO-I as a reference material. Accuracy and precision of the XRF analyses are estimated to be $\pm 2 \%$ for major oxides present in concentrations greater than $0.5 \mathrm{wt} \%$ and $\pm 5 \%$ for trace elements. Accuracy and precision of the ICP-MS analyses are better than $\pm 5 \%$ (Zhou ef al. 2000).

$\mathrm{Sm}$-.-Nol isotopic analyses were performed on a VG-354 mass spectrometer at the Institute of Geology and Geophysics, Chinese Academy of Sciences, Beijing. The mass fractionation corrections for Nd isotopic ratios were based on ${ }^{146} \mathrm{Nd} /{ }^{144} \mathrm{Nd}=0.7219$. Detailed sample preparation and analytical procedures have been given by Zhang ef $a l .(2001)$.

\section{Geochemistry of the basalts}

The Upper Permian metabasalts of the Songpan Ganzi and Yidun terranes were metamorphosed under greenschist-facies conditions during Mesozoic-Cenozoic tectonometamorphic cvents (Huang et al. 2003), but this does not seem to have significantly modified their major oxide compositions. $\mathrm{MgO}$

Table 1. Contents of major oxides (wt\%) and trace element abundances (ppm) of the Upper Permian metabasalts and gabbro in the Songpan-Ganzi and Yidun terranes

Tonglufang cross-section, Danba, Songpan-Ganzi Terrane

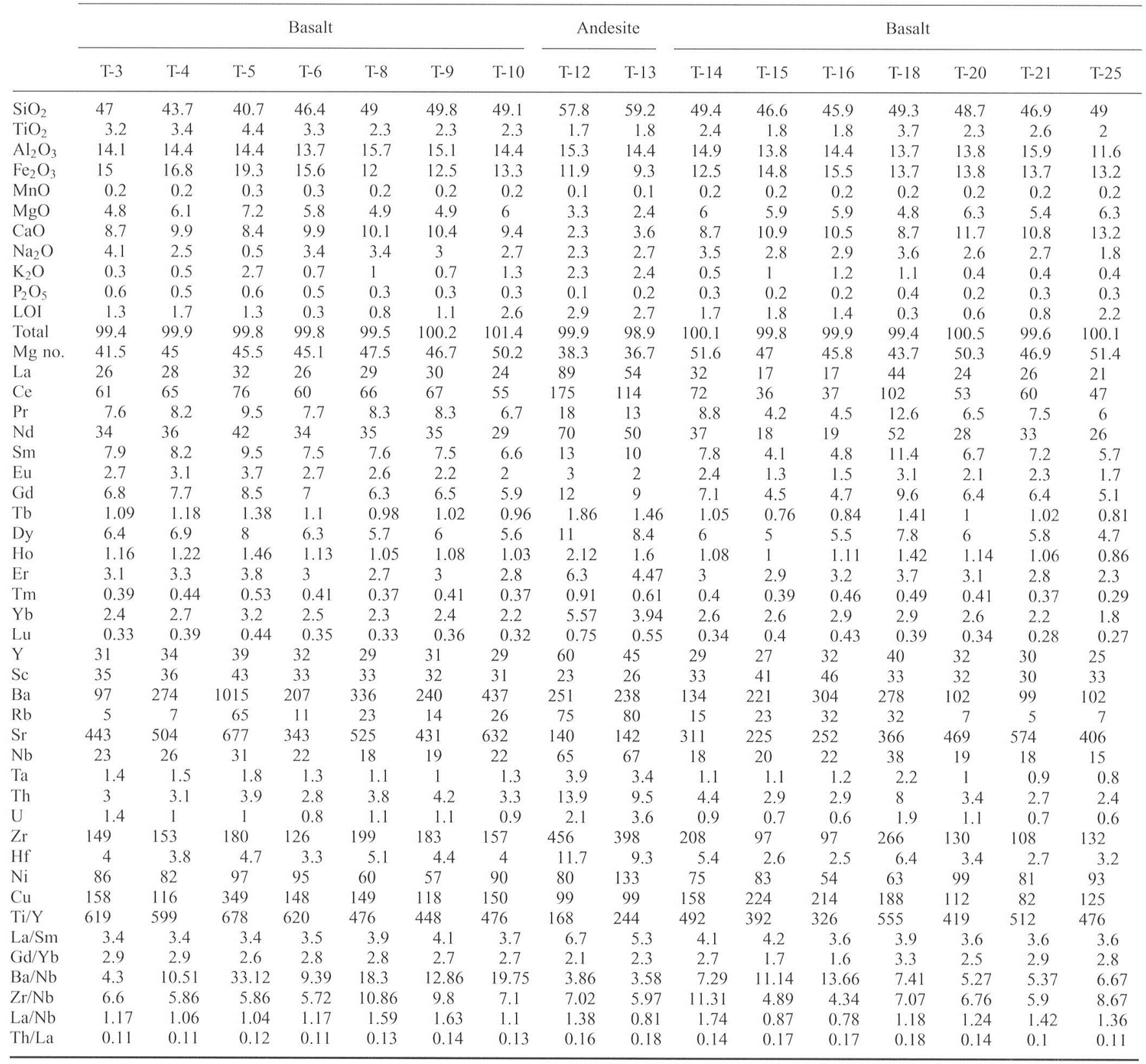

$\mathrm{Fe}_{2} \mathrm{O}_{3}$ represents total Fe. LOI, loss on ignition. 
contents range from 4.8 to $7.2 \mathrm{wt} \%, \mathrm{SiO}_{2}$ from 39.2 to $49.8 \mathrm{wt} \%$, and $\mathrm{TiO}_{2}$ from 1.6 to $4.2 \mathrm{wt} \%$ (Table 1). $\mathrm{Mg}$ numbers, where Mgnumber $=100 \mathrm{Mg}^{2+} /\left(\mathrm{Fe}^{2+}+\mathrm{Mg}^{2+}\right)$ and $\mathrm{Fe}^{2+}$ is $89 \%$ total iron, range from 40.1 to 54.1. On a $\mathrm{SiO}_{2}$ v. $\left(\mathrm{Na}_{2} \mathrm{O}+\mathrm{K}_{2} \mathrm{O}\right)$ diagram (Le Maitre et al. 1989) the lavas from the SongpanGanzi Terrane plot chiefly in the basalt field on both sides of the alkali-tholeiite boundary as defined by Irvine \& Baragar (1971) (Fig. 4). Those from the Yidun Terrane mostly lie in the field of alkali basalts. All but three of the analysed samples plot in the Emeishan continental flood basalts field as defined by Song et al. (2001) and Xu et al. (2001) (Fig. 4). On plots of Mg number v.
$\mathrm{TiO}_{2}, \mathrm{Fe}_{2} \mathrm{O}_{3}, \mathrm{Al}_{2} \mathrm{O}_{3}$ and $\mathrm{Na}_{2} \mathrm{O}+\mathrm{K}_{2} \mathrm{O}$ the lavas also elearly lie within the field of the Emeishan continental flood basalts of the South China Craton (Fig. 5).

Consistent with the major oxide geochemistry, chondritenormalized REE patterns of the Upper Permian metabasalts of the Songpan-Ganzi and Yidun terranes are virtually identical to those of the type Emcishan basalts. All of the analysed samples are characterized by marked light Rlil: enrichment (LREE; $\mathrm{La} / \mathrm{Sm}=3.4 .4 .3$ ) and heavy RI:I depletion (HRI:I; $\mathrm{Gd} / \mathrm{Yb}=2.4-3.0$ ) (Table 1, Fig. Ga and b). Primitive mantlenormalized trace element patterns show that all the basalts are

\begin{tabular}{|c|c|c|c|c|c|c|c|c|c|c|c|c|c|}
\hline \multicolumn{14}{|c|}{ Bogexi cross-section, Yidun, Yidun Terrane } \\
\hline \multicolumn{14}{|c|}{ Basalt } \\
\hline B02-1 & B02-2 & B02-3 & B02-4 & B02-5 & B02-13 & B02-14 & B02-15 & B02-16 & B02-17 & B02-18 & B02-19 & B02-20 & B02-21 \\
\hline 45.4 & 45.6 & 48 & 46.9 & 48 & 44.5 & 46.6 & 46.8 & 46.6 & 47.8 & 45.8 & 46.3 & 46 & 46.9 \\
\hline 3.3 & 3.4 & 2.7 & 2.5 & 2.5 & 3.8 & 2.9 & 2.8 & 3.4 & 3.3 & 3.2 & 2.8 & 2.6 & 3.5 \\
\hline 13.5 & 13.5 & 14 & 14 & 13.7 & 13.8 & 13.2 & 13.7 & 13.3 & 12.8 & 13.3 & 13.7 & 12.8 & 13.3 \\
\hline 15.7 & 15.6 & 13.2 & 12.5 & 12.9 & 15.2 & 15 & 14.3 & 15.2 & 15.4 & 14.9 & 14.1 & 13.4 & 15.2 \\
\hline 0.2 & 0.2 & 0.2 & 0.2 & 0.2 & 0.2 & 0.2 & 0.2 & 0.3 & 0.3 & 0.2 & 0.2 & 0.2 & 0.2 \\
\hline 5.4 & 5.3 & 5.7 & 6.6 & 6.3 & 6.3 & 5 & 5.6 & 5.1 & 4.6 & 6.7 & 5.4 & 4.8 & 4.9 \\
\hline 9.4 & 9.3 & 8.9 & 10.4 & 9.7 & 7.1 & 8.7 & 6.8 & 10 & 6.4 & 5.9 & 8.2 & 10 & 6.3 \\
\hline 3.1 & 3.1 & 3 & 2.6 & 2.9 & 2.8 & 3.1 & 3.6 & 2.5 & 3.8 & 3.4 & 3.5 & 2.9 & 3.6 \\
\hline 1 & 0.9 & 1.3 & 0.9 & 0.8 & 1.2 & 1 & 1.2 & 1.1 & 0.5 & 0.9 & 1.4 & 1.1 & 0.7 \\
\hline 0.6 & 0.6 & 0.4 & 0.4 & 0.3 & 0.8 & 0.6 & 0.6 & 0.6 & 0.7 & 0.6 & 0.6 & 0.5 & 0.7 \\
\hline 1.9 & 2 & 2.2 & 2.3 & 2 & 3.7 & 3 & 3.9 & 2.6 & 3.8 & 3.6 & 3 & 4.7 & 3.5 \\
\hline 99.4 & 99.5 & 99.7 & 99.3 & 99.3 & 99.5 & 99.5 & 99.5 & 100.7 & 99.3 & 98.4 & 99.3 & 99.1 & 98.9 \\
\hline 43.6 & 42.9 & 49.1 & 54.1 & 52.4 & 48.1 & 42.8 & 46.6 & 42.9 & 40.1 & 50 & 46 & 44.5 & 42 \\
\hline 30 & 33 & 28 & 23 & 24 & 31 & 38.46 & 36 & 34 & 34 & 32 & 36 & 31 & 37 \\
\hline 68 & 74 & 61 & 53 & 54 & 70 & 85.38 & 81 & 76 & 75 & 72 & 77 & 70 & 83 \\
\hline 9 & 9.6 & 7.8 & 6.9 & 7 & 9.2 & 11.11 & 10.7 & 9.7 & 9.8 & 9.3 & 9.9 & 9.2 & 10.9 \\
\hline 39 & 42 & 33 & 30 & 30 & 40 & 47.61 & 46 & 42 & 42 & 40 & 42 & 39 & 47 \\
\hline 7.9 & 8.4 & 7.2 & 6.5 & 6.5 & 8.2 & 9.47 & 9.8 & 8.8 & 8.9 & 8.6 & 8.2 & 8.4 & 10 \\
\hline 3.1 & 3.2 & 2.5 & 2.2 & 2.2 & 3.4 & 3.37 & 3.9 & 3.1 & 2.8 & 3.1 & 2.8 & 3.3 & 3.2 \\
\hline 6.8 & 7.2 & 6.7 & 6.1 & 6 & 7.2 & 8.17 & 9.1 & 8.2 & 8.3 & 7.9 & 7.2 & 7.8 & 9.1 \\
\hline 1.07 & 1.16 & 1.13 & 1.04 & 1.02 & 1.12 & 1.3 & 1.52 & 1.38 & 1.37 & 1.33 & 1.15 & 1.31 & 1.55 \\
\hline 5.7 & 6.1 & 6.4 & 5.8 & 5.7 & 6.1 & 6.87 & 8.4 & 7.7 & 7.5 & 7.4 & 6.1 & 7.2 & 8.5 \\
\hline 1.11 & 1.16 & 1.24 & 1.13 & 1.14 & 1.15 & 1.32 & 1.62 & 1.5 & 1.47 & 1.43 & 1.18 & 1.41 & 1.64 \\
\hline 3 & 3.1 & 3.4 & 3 & 3 & 3.1 & 3.51 & 4.3 & 3.9 & 3.9 & 3.9 & 3.1 & 3.8 & 4.4 \\
\hline 0.35 & 0.38 & 0.44 & 0.39 & 0.4 & 0.38 & 0.43 & 0.55 & 0.5 & 0.49 & 0.49 & 0.38 & 0.48 & 0.56 \\
\hline 2.3 & 2.5 & 2.8 & 2.6 & 2.5 & 2.4 & 2.81 & 3.6 & 3.3 & 3.3 & 3.2 & 2.5 & 3.1 & 3.6 \\
\hline 0.33 & 0.36 & 0.42 & 0.37 & 0.37 & 0.36 & 0.41 & 0.53 & 0.48 & 0.47 & 0.47 & 0.36 & 0.47 & 0.53 \\
\hline 27 & 28 & 31 & 28 & 28 & 28 & 32.71 & 40 & 36 & 37 & 36 & 29 & 36 & 41 \\
\hline 25 & 25 & 28 & 29 & 28 & 31 & 25.3 & 31 & 26 & 25 & 28 & 24 & 26 & 29 \\
\hline 543 & 482 & 279 & 241 & 254 & 414 & 582 & 422 & 415 & 1155 & 427 & 590 & 649 & 311 \\
\hline 27 & 18 & 25 & 26 & 16 & 32 & 32.09 & 23 & 39 & 18 & 19 & 26 & 27 & 17 \\
\hline 495 & 560 & 580 & 270 & 351 & 346 & 879 & 206 & 950 & 262 & 147 & 355 & 540 & 433 \\
\hline 24 & 26 & 23 & 20 & 21 & 25 & 26.66 & 29 & 28 & 28 & 26 & 26 & 26 & 30 \\
\hline 1.6 & 1.7 & 1.5 & 1.3 & 1.4 & 1.7 & 1.7 & 1.9 & 1.9 & 1.8 & 1.7 & 1.6 & 1.7 & 2 \\
\hline 3.2 & 3.4 & 3.8 & 3.1 & 3.3 & 3.1 & 3.8 & 4.7 & 4.2 & 4.2 & 4 & 3.5 & 4.1 & 4.7 \\
\hline 0.8 & 0.9 & 1 & 0.8 & 0.9 & 0.8 & 0.95 & 1.2 & 1.1 & 1.1 & 1.1 & 0.8 & 1.2 & 1.3 \\
\hline 166 & 177 & 189 & 177 & 184 & 163 & 178 & 226 & 213 & 212 & 206 & 166 & 205 & 233 \\
\hline 4.3 & 4.5 & 4.8 & 4.5 & 4.7 & 4.2 & 4.41 & 5.8 & 5.5 & 5.4 & 5.2 & 4.1 & 5.2 & 6.2 \\
\hline 50 & 45 & 86 & 118 & 106 & 88 & 42.2 & 53 & 49 & 43 & 57 & 47 & 49 & 47 \\
\hline 73 & 78 & 88 & 144 & 138 & 135 & 104.3 & 66 & 77 & 47 & 71 & 70 & 72 & 53 \\
\hline 751 & 720 & 522 & 546 & 531 & 812 & 540 & 418 & 564 & 535 & 529 & 585 & 434 & 515 \\
\hline 3.8 & 3.9 & 3.8 & 3.6 & 3.7 & 3.8 & 4.1 & 3.7 & 3.8 & 3.7 & 3.7 & 4.3 & 3.7 & 3.7 \\
\hline 3 & 2.9 & 2.4 & 2.4 & 2.4 & 2.9 & 2.9 & 2.6 & 2.5 & 2.5 & 2.5 & 2.9 & 2.5 & 2.5 \\
\hline 22.39 & 18.59 & 12.08 & 11.82 & 12.01 & 16.86 & 21.83 & 14.33 & 14.94 & 41.63 & 16.34 & 23.03 & 24.56 & 10.2 \\
\hline 6.83 & 6.85 & 8.17 & 8.68 & 8.67 & 6.64 & 6.64 & 7.66 & 7.66 & 7.64 & 7.89 & 6.49 & 7.77 & 7.65 \\
\hline 1.25 & 1.27 & 1.2 & 1.15 & 1.14 & 1.27 & 1.27 & 1.24 & 1.21 & 1.21 & 1.23 & 1.39 & 1.19 & 1.21 \\
\hline 0.1 & 0.1 & 0.14 & 0.13 & 0.14 & 0.1 & 0.1 & 0.13 & 0.12 & 0.12 & 0.12 & 0.1 & 0.13 & 0.13 \\
\hline
\end{tabular}




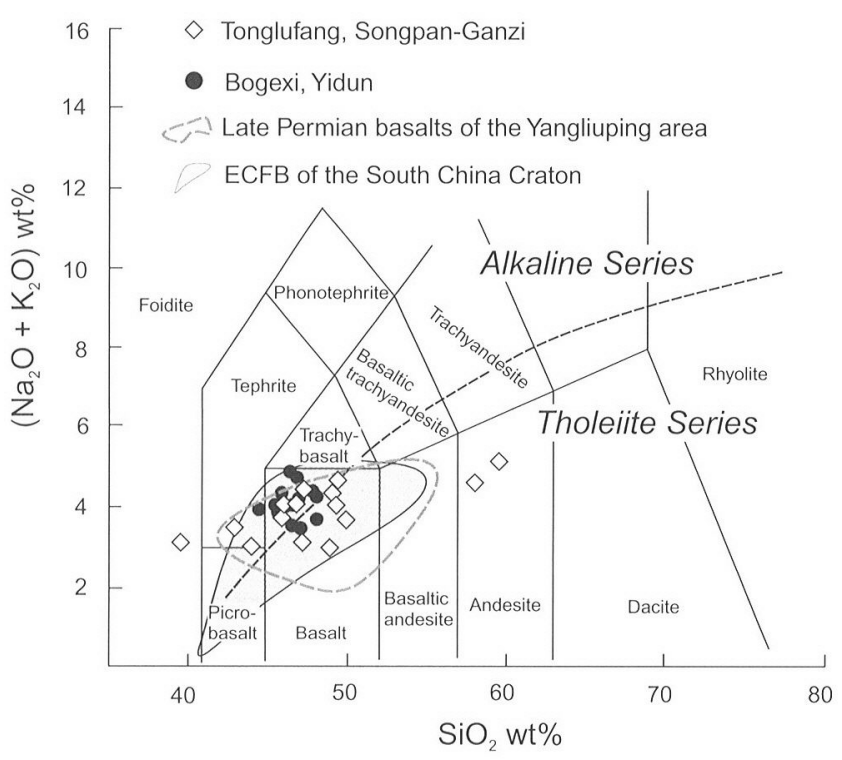

Fig. 4. Chemical classification and nomenclature of volcanic rocks using the total alkalis v. silica (TAS) diagram of Le Maitre et al. (1989). The subdivision of alkaline and tholeiitic series is after Irvine \& Baragar (1971). Data for the Emeishan continental flood basalts are after Song et al. (2001) and Xu et al. (2001). ECFB, Emeishan continental flood basalts.

enriched in both high field strength elements and large ion lithophile elements (Fig. 60 and d) (Song et al. 2001; Xu et al. $2001)$.

The geochemical data also suggest that the parental melts of the Yidun and Songpan Ganzi basalts were predominantly derived from the Emeishan plume. The basalts have variable trace element ratios, such as $\mathrm{Zr} / \mathrm{Nb}(4.34-11.31), \mathrm{La} / \mathrm{Nb}(0.73$ 1.74), $\mathrm{Ba} / \mathrm{Nb}(4.30-41.63)$ and $\mathrm{Th} / \mathrm{La}(0.10-0.19)$ (Table 1), that are virtually identical to those of the Emeishan continental flood basalts (Song et al. 2001). In a $\mathrm{Ce} / \mathrm{Nb}$ v. Th/ $\mathrm{Nb}$ diagram, the Upper Permian metabasalts clearly lie in the field of the Emeishan continental flood basalts and extend from ocean-island basalt (OIB) to the ficld of intra-oceanic are basalts (Fig. 7). This trend can be interpreted in terms of interaction between primitive magmas and the subcontinental lithosphere (Davies ot al. 1989; Hofmann 1997; Green \& Falloon 1998; Hauff et al. 2000).

In addition, the metabasalts and gabbros of the Songpan-Ganzi and Yidun terranes have similar $C_{\text {Nd(1) }}$ values (-.0.3 to 4.8 ) (Table 2), which plot within the field defined by the Emeishan continental flood basalts $(-6$ to +6$)$ (Fig. 8) (Xu ef al. 2001).

The similar geochemical characteristics outlined above indicate that the parental melts of the basalts of the Songpan Ganzi and Yidun terranes were derived from the same source regions as the Emeishan continental flood basalts. Song et al. (2001) proposed that the primitive magmas of the Emeishan continental flood basalts were produced by partial melting of a rising mantle plume that reacted with the lithospheric mantle, which had been previously modified and enriched by pelagic sediments during Neoproterozoic subduction. The depletion of HIRIS and the large $\mathrm{Gd} / \mathrm{Yb}$ ratios in these rocks are interpreted to reflect partial melting of garnet therzolite at depths of $60.70 \mathrm{~km}$ or morc.

In summary, all of the geochemical characteristics described above support the correlation of the Upper Permian metabasalts in the Songpan-Ganzi and Yidun terranes with those in the lype location of the Emeishan flood basalts and indicate that they were derived from the same melt source regions.

\section{Tectonic implications}

One of the most important regional geological problems in eastern Tibet is the origin of the Songpan Ganzi basin and the Triassic flysch with which it is filled. Some workers have suggested that the flysch detritus was derived from the Sulu-. Dabic orogenic belt and deposited in a remnant ocean basin (Yin \& Nic 1993; Zhou \& Graham 1996; Ingersoll et al. 1995).
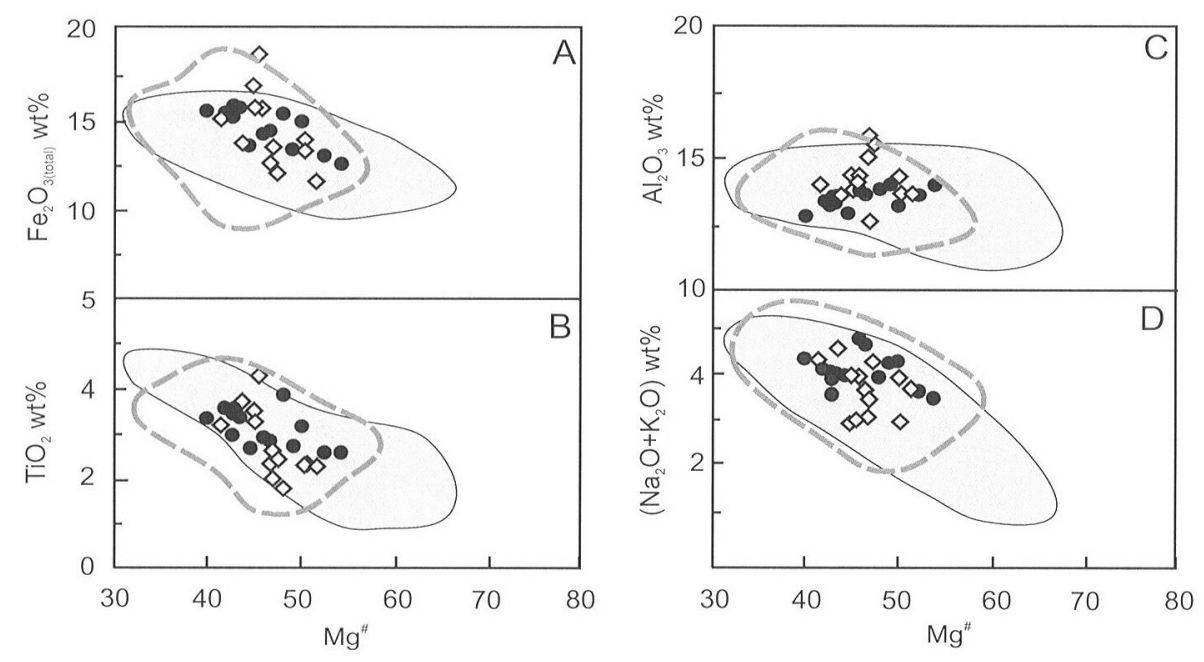

$\diamond \quad$ Tonglufang, Songpan-Ganzi

- Bogexi, Yidun

8. Late Permian basalts of the Yangliuping area ECFB of the South China Craton
Fig. 5. Correlation between $\mathrm{Mg}$ number and oxides. The compositions of the Emeishan continental flood basalts (ECFB) are represented by the shaded areas. The fields circled by dashed lines represent the compositions of the basalts in the Danba area (unpublished data). Data for the Emeishan continental flood basalts are after Song et al. (2001) and Xu et al. (2001). 

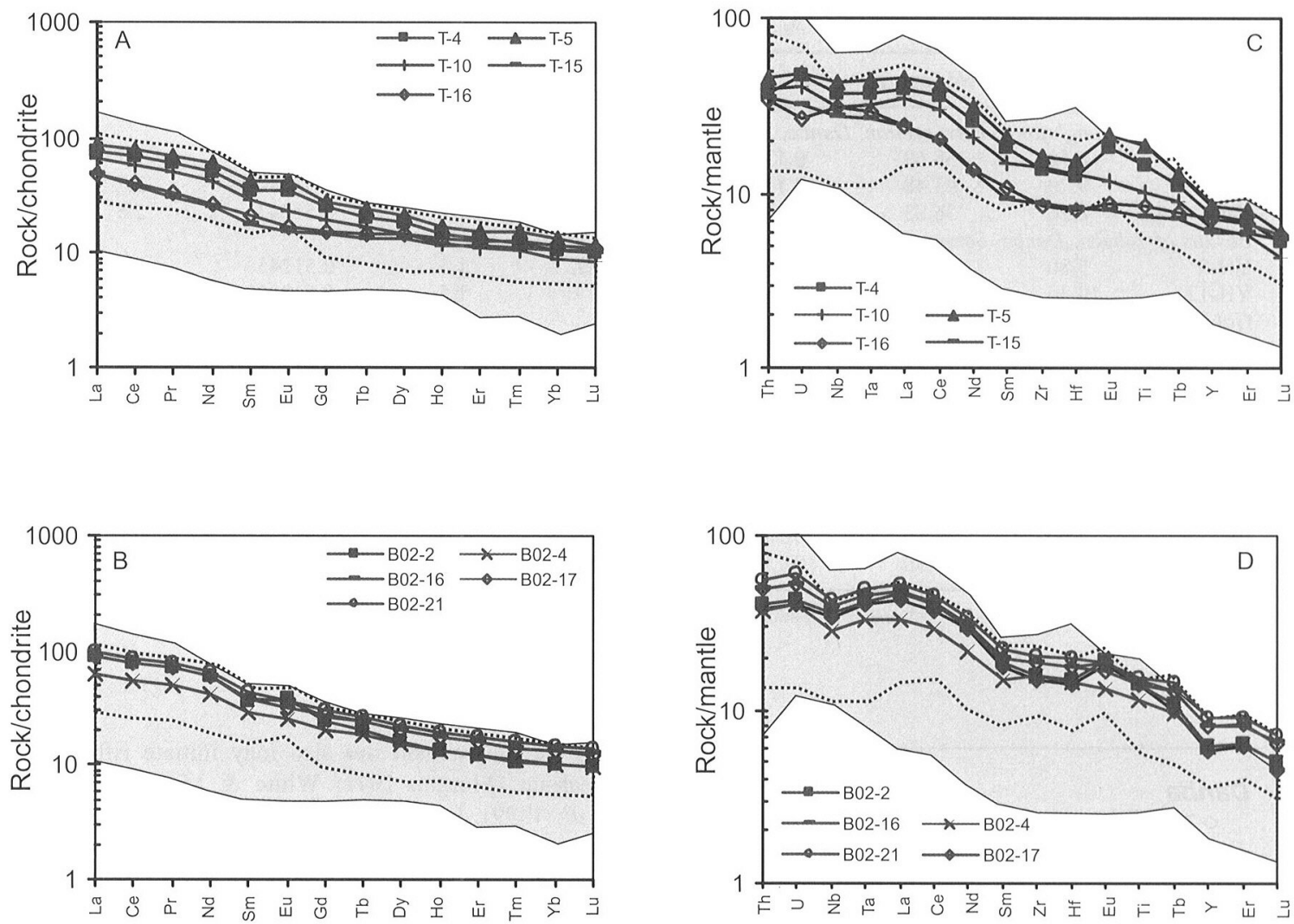

Fig. 6. (a, b) Selected chondrite-normalized REE patterns of Upper Permian basalts in the Songpan-Ganzi and Yidun terranes: (a) Tonglufang section, Danba; (b) Bogexi section, Yidun. Normalization values are after Taylor \& McLennan (1985). (c, d) Selected primitive mantle-normalized trace-element patterns of Upper Permian basalts in the Songpan-Ganzi and Yidun terranes: (c) Tonglufang section, Danba; (d) Bogexi section, Yidun. Primitive mantle values are after Hofmann (1988). The shaded areas show the limits of the Emeishan continental flood basalts, data after Song et al. (2001) and Xu et al. (2001). The fields circled by dashed lines mark the limits of the basalts in the Danba area (unpublished data).

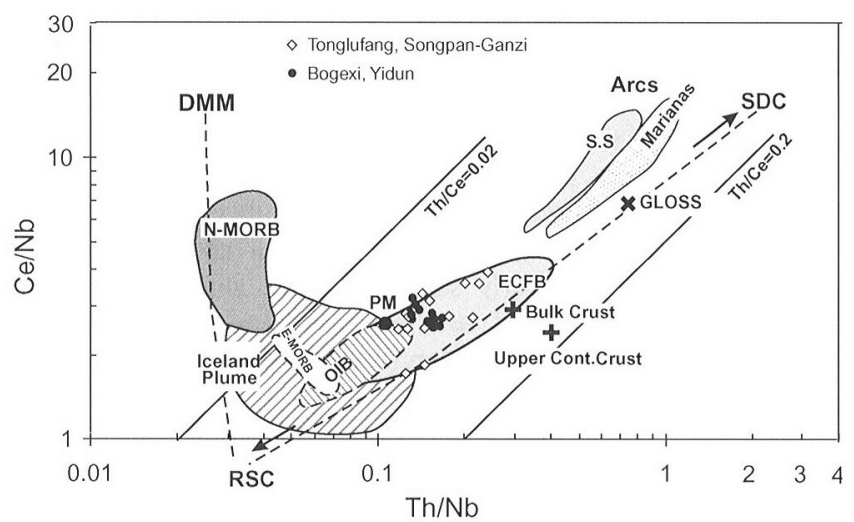

Fig. 7. Diagram of Ce/Nb v. Th/Nb. The Upper Permian metabasalts plot within the field of the Emeishan continental flood basalts. DMM, depleted mantle; SDC, recycled subduction-derived component; S.S, subducting sediments in ares; RSC, recycled residual slab composition; OIB, ocean-island basalt; N-MORB, normal mid-ocean ridge basalt; EMORB, enriched MORB; PM, primitive mantle. The compositions of upper continental crust and bulk continental crust are modified fromSaunders et al. $(1988,1991)$. Data for the Iceland plume are from Hemond et al. (1993). Fields for arcs are from Saunders et al. (1991). Global subducting sediment composition (GLOSS) is from Plank \& Langmuir (1998).
However, the remnant occan basin model poses several problems. First, similar Neoproterozoic rocks and Sinian - Palacozoic sedimentary rocks occur on the eastern margins of the Songpan Ganzi Yidun terranes and the western margin of the South China Craton (Fig. 3). Second, this model docs not account for the presence of the Emeishan continental flood basalts in the Songpan-Ganzi and Yidun terranes (Fig. 1). Finally, the geochemistry of early Mesozoic plutons within the Songpan-... Ganzi Terrane suggests that they were derived from underlying continental crust (Burchfiel et al. 1995). Chang (2000) proposed that a triple junction developed in the Songpan-Ganzi Terrane during the Permian and detritus from the Dabie-Sulu belt and adjacent areas filled the new oceanic basin. However, Chang's model does not address the cause of rifting in the Late Permian.

Correlation of the Neoproterozoic and Palacozoic rocks in the Songpan-Ganzi and Yidun terranes along the eastern edge of the Tibet Plateau with those of the South China Craton indicates that these regions were contiguous until the Late Permian. Identificittion of Emeishan basalts on both sides of the (janzi Litang suture indicates that the Songpan-Ganzi ocean basin opened in the latest Permian by break-up of the South China Craton. The spatial and temporal relationships between the break-up and the development of the Emeishan basalts suggest that the initial rifting and development of the ocean basin at the triple junction were a response to the plume activity. Extensive uplift of the lithosphere along the western margin of the South (hina Craton, 
Table 2. Sm-Nd isotopic data for the Upper Permian metabasalts of the Songpan-Ganzi and Yidun terranes

\begin{tabular}{lccccccc}
\hline Sample & $\mathrm{Sm}(\mathrm{ppm})$ & $\mathrm{Nd}(\mathrm{ppm})$ & ${ }^{147} \mathrm{Sm} /{ }^{144} \mathrm{Nd}$ & ${ }^{143} \mathrm{Nd} /{ }^{144} \mathrm{Nd}$ & $\pm 2 \sigma\left(\times 10^{5}\right)$ & ${ }^{143} \mathrm{Nd}^{144} \mathrm{Nd}_{\mathrm{t}}$ & $\varepsilon \mathrm{Nd}(260 \mathrm{Ma})$ \\
\hline Basalts of the Tonglufang & cross- section, & Danba, Songpan-Ganzi Terrane & & & & \\
T-4 & 8.68 & 38.69 & 0.136 & 0.512621 & 1.1 & 0.51239 & 1.7 \\
T-5 & 9.70 & 43.48 & 0.135 & 0.512671 & 1.0 & 0.51244 & 2.7 \\
T-6 & 8.20 & 36.83 & 0.135 & 0.512661 & 1.1 & 0.51243 & 2.5 \\
Basalts of Yuhaizi, Danba, Songpan-Ganzi Terrane & & & & \\
YH-9 & 7.80 & 34.95 & 0.135 & 0.512681 & 1.5 & 0.51245 & 2.9 \\
YH-12 & 10.36 & 47.29 & 0.133 & 0.512773 & 1.5 & 0.51255 & 4.8 \\
Gabbro of the Yuhaizi intrusion, Danba, SGT & & & & & \\
YH-31 & 7.82 & 33.58 & 0.141 & 0.512699 & 0.8 & 0.51246 & 3.1 \\
YH-34 & 3.94 & 15.05 & 0.158 & 0.5127 & 1.0 & 0.51243 & 2.5 \\
YH-36 & 3.39 & 12.88 & 0.159 & 0.512751 & 1.4 & 0.51248 & 3.5 \\
Basalts of the Bogexi cross-section, Yidun, Yidun Terrane & & & & \\
B02-13 & 8.26 & 40.28 & 0.124 & 0.51254 & 1.4 & 0.51233 & 0.5 \\
B02-15 & 10.19 & 47.31 & 0.130 & 0.512508 & 1.0 & 0.51229 & -0.3 \\
B02-16 & 9.61 & 43.28 & 0.134 & 0.512534 & 1.1 & 0.51231 & 0.04 \\
B02-18 & 8.60 & 39.16 & 0.133 & 0.512561 & 0.9 & 0.51234 & 0.6 \\
B02-20 & 8.57 & 38.56 & 0.134 & 0.512584 & 1.1 & 0.51236 & 1.0 \\
\hline
\end{tabular}

${ }^{143} \mathrm{Nd} /{ }^{144} \mathrm{Nd}$ normalized to ${ }^{146} \mathrm{Nd} /{ }^{144} \mathrm{Nd}=0.7219$. Estimated overall error is \pm 0.000020 .

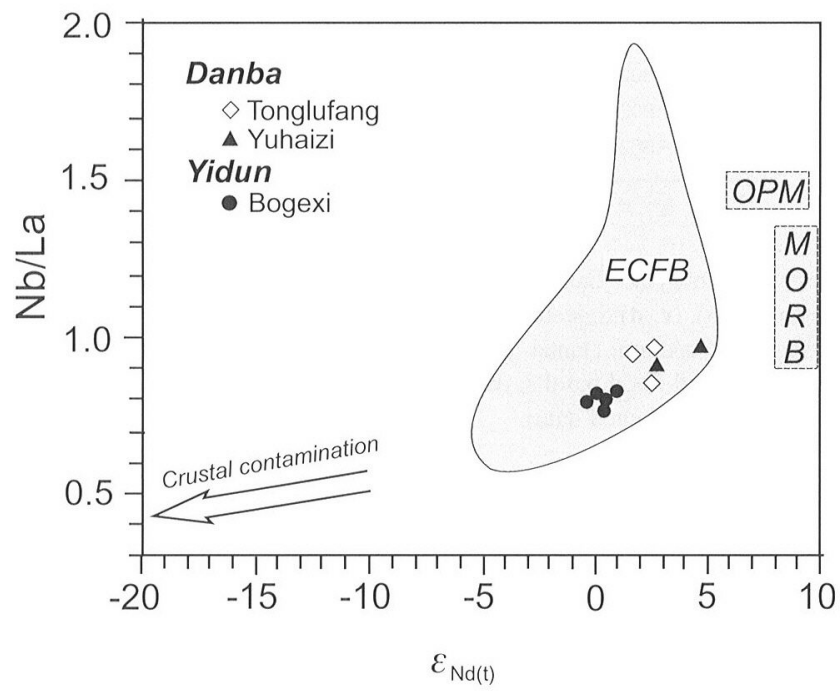

Fig. 8. Correlation between $\mathrm{Nb} / \mathrm{La}$ and $\epsilon_{\mathrm{Nd}(t)}$ of the Upper Permian metabasalts from Danba and Yidun. The field of the Emeishan continental flood basalts (ECFB) is from Xu et al. (2001). OPM, average oceanic plume magma (Gibson et al. 1996). The tendency of crustal contamination is modified from Weaver \& Tarney (1984), Taylor \& McLennan (1985) and Wilson (1989).

prior to cruption of the basalts, is indicated by the disconformity between the Lower Permian limestone or marble and the Emeishan continental flood basalts. As the mantle plume welled upward during lithospheric thinning and extension, rapid decompressional melting produced huge volumes of magma. Continued rifting is believed to have led to formation of the SongpanGanzi ocean basin, which was later filled with huge quantities of clastic sediment. Westward subduction of the Songpan Ganzi oceanic lithosphere in the Late Triassic caused extensive calcalkaline volcanism and intrusion along the Yidun Terrane in the Late Triassic (Hou el al. 2001)

Other workers have previously proposed that the sublithospheric impact of mantle plumes not only causes extensive basaltic magmatism but also may initiate rifting and continent break-up (Morgan 1971; White \& McKenzic 1995; Courtillot et al. 1999). For example, fragmentation of Pangaca during the Mesozoic and Cenozoic has been linked to mantle plume impact (Dalzicl et al. 2000), and Courtiliot ef al. (1999) suggested that a huge extensional basin, which opened in the latest Permian or earliest Triassic at the western margin of the Siberian Traps, may have been triggered by the mantle plume from which the parental melts of the basalts were derived. The relationship between activity of the Emeishan mantle plume and opening of the Songpan-Ganzi ocean basin and break-up of the South China Craton provides another example.

\section{Conclusions}

The Upper Permian lavas in the Songpan-Ganzi and Yidun terranes represent distal members of the Lmeishan continental flood basalts produced by the Emeishan mantle plume. Uplift and extension of the lithosphere by the mantle plume in the Late Permian caused the formation of a triple junction in the region, break-up of the South China Craton and opening of the Songpan Ganzi ocean basin. The Iimeishan continental flood basalts erupted in the carly stages of uplift and rifting of the South China Craton, and are considered to be tectonically equivalent to dipping reflectors on modern ocean margins.

This study was supported by the Research Grant Council of the llong Kong SAR, China (IIKU7101/01P and HKU7056/03P) to M.-I.7. A postgraduate studentship from the University of Hong Kong, and grants from China (NSIC Nos 40373030) and 40273025) to X.-Y.S. are acknowledged.

\section{References}

All, J.-R., Thompson, G.-M., Sonci, X.-Y. \& Wang, Y.-L. 2002 . Emeishan Basalts (SW (hina) and the 'end-(juadatupian' erisis; magnetobiostratigraphic constraints. Foumal of the Goologion Socton, london, 159, 2129.

BGMS 1991. Regional Goology of Sichuan Province. Burcilu ol Geology and Mineral Resources of Sichuan Province. Cieological l’ublishing House, Beijing.

Brusiult:R, O. \& MAl,AvIEIl,L.F, J.R. 1997. U Pb dating on single dutrital zircon granites from the Triassic Songpan (janzi flysch (central (hina); provenance

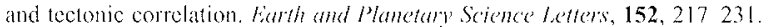


Burchiliz, B.C., Chin, Z., Liu, Y, \& Roydin, L.H. 1995. Tectonics of the Longmen Shan and adjacent regions, central China. Intemational Geology Review, 37, 661 735 .

Cinang, E. 2000. Geology and tectonics of the Songpan-Ganzi fold belt, Southwestern China. International Geology Review, 42, 813-831.

Chunc, S.I. \& JAHN, B.-M. 1995. Plume-lithosphere interaction in generation of the Emeishan flood basalts at the Permian-Triassic boundary. Geology; 23, 889892.

Courtiliot, V., Jaupart, C., Manighelti, P. \& Besse, J. 1999. On causal links between flood basalts and continental break-up. Earth and Planetary Science Letle's, 166, 177-195.

Dhizili., I.W.D., Lawvir, I.A. \& Murphy, J.B. 2000. Plumes, orogenesis, and supercontinental fragmentation. Earth and Planetary Sciences Letters, 178, $1-11$.

Davils, G.R., Norry, M.J., Girlach, D.C. \& ClifF, R.A. 1989. A combined chemical and $\mathrm{Pb} \cdot \mathrm{Sr} \cdots \mathrm{Nd}$ isotope sudy of the Azores and Cape Verde lotspots: the geodynamic implications. In: SAunders, A.D. \& Norry, M.J. (cds) Magmatism in the Ocean Basins. Geological Socicty, London, Special Publications, 42, 231256

Gibson, S.A., Thompson, R.N., Dickin. A.P. \& Llionnroos, O.H. 1996. Mafic potassic magmatic kcy to phume--lithosphere interactions and continental flood-basalts. Earth and Planetary Science Letlers, 141, 325--341.

Gresn, D.H. \& FalloON, T.J. 1998. A Ringwood concept and its current

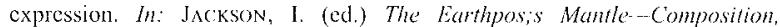
Structure, and Evolution. Cambridge University Press, Cambridge, 311-381.

Hauji, H., Holrniti, K., Til.ton, G., Graham, D.W. \& Ki:rr, A.C. 2000. Large volume recycling of oceanic lithosphere over short time scale: geochemical constraints from the Caribbean Large Igneous Province. Earth and Planetary Science Letters, 174, 247-263.

Hemont, C., Arnit, N.T., Lichtinstiein, U., Holmann, A.W. Oskarsson, N. \& Strinthorsson, S. 1993. The heterogeneous leeland plume: $\mathrm{Nd} \cdots \mathrm{Sr}-\mathrm{O}$ isotope and trace element constraints. Jounal of Geophlysical Rescarch, 98, 1583315850 .

HOFMnNN, A.W. 1988. Chemical differentiation of the Farth: the relationship between mantlc, continental crust, and oceanic crust. Earth and Planctary Science Letters, 90, 297 -314.

Hormann, A.W. 1997. Mantle geochemistry: the message from oceanic volcanism. Natue, 385, 219229.

Hou, Z.Q., Chr N, W. \& Lu, J.R. 2001 Collision event during 177-135 Ma on the castern margin of the Qinghai-Tibetan Plateau: evidence from ${ }^{40} \mathrm{Ar} /{ }^{31} \Lambda \mathrm{r}$ dating for basalts on the western margin of the Yangtze platform. Acta Geologica Sinica, 76(2), 194-204.

Hunne, K.N., Opuyki, N.D., Kent, D.V., Xu, G.Z. \& 'T'ang, R.L. 1986. Further paleomagnetic results from the Permian Emeishan basalts in SW China. Kevue Tongbur, 31, 1195-1201 (in Chinese)

Huanci, H., MaAs, R., Buick, I.S. \& Williams, I.S. 2003. Crustal response to continental collisions between the Tibet, India, South China and North China Blocks: geochronological constraints from the Songpan-Ganze Orogenic Belt, western China. Joumal of Metamorphic Geology, 21, 223-240

Ingiiksol.l, R.V., Grnham, S.A. \& Dickinson, W.R. 1995. Remnant-ocean-basins, In: Busby, C. \& Ingilissoll., R.V. (cds) Tectonics of Sedimentary Basins. Blackwell, Oxford, 1-51.

Irvine, T.N. \& BARAgar, W.R.A. 1971. A guide to the chemical classification of common volcanic rocks. Canadian toumal of Earth Sciences, 8, 523-548.

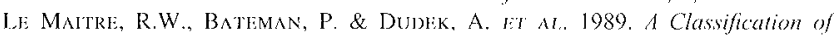
lgneous Rocks and Glossary of Tems. Blackwell Scientific, London.

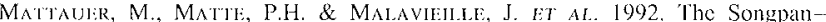
Ganzi Triassic belt of $W$ Sichuan on castern Tibet. Comptes Rendus de l'Academie des Sciences, Serie 2, 314, 619626

Mo, X.X., Lu, F.X. \& SHEN, S.Y. Iij M. 1993. Volcanism and Mineralization in the Sanjiang Tethys. Geological Publishing Housc, Bcijing (in Chinesc).

Morrian, W.J. 1971. Convection plumes in the lower mantle. Nature, 230, 42-43.

Pt.ANK, T. \& Langmurr, C.H. 1998. The chemical composition of subducting sediment and its consequences for the crust and mantle. Chemical Geology,
I45, 325-394.

Rogite, F. \& CanAssou, S. 1997. Géchronologie Ul Pb sur zircons at géochimic

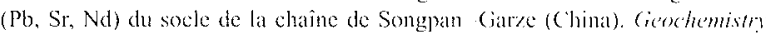
324,819826

SAUndizs. A.D., Norky. M.J. \& Thanliy, J, 1988. Origin of MORBb and chemically depleted mantle reservoirs: Irace element constraints. Jommal of Petwology: Sorecial lithosphere Lswer, 415445.

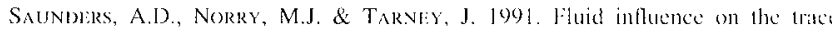
element compositions of subduction zone magmas. Philoxophical Trumsat tions of the Royal Societs London, Sories A, 335, 337392

Singor, A.M.C. \& NATAl"iN, B.A. 1996. Palcotectonics of Asia: fraglnests of : synthesis. In: YIN, A. \& HARrison. M. (eds) The Tectonic Liolution of Isia Cambridge University Press, Cambridere, $486 \quad 640$.

SONG, X.-Y., ZHOU, M.-F., Hou, Z.-Q., CAO, Z.-M., WANG. Y.-I. \& H., Y... 2001. Geochemical constraints on the mantle source of the lyper Permian Encishan continental food basalts, Southwestern (hinat. Intomational Geology Revien, 43, 213-225.

Song, X.-Y., Znou, M.-F., CAO, Z.-M., Sun, M. \& Wanci, Y.-I.. 2003. The Ni $\mathrm{Cu}-(\mathrm{PGF})$ magmatic sulfide deposits in the Yangliuping anea within the Permian Fmeishan Large Igneous Province, SW China. Mimeraliam /reposita 38,831843 .

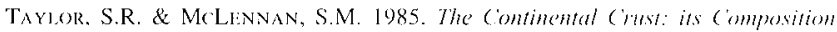
and Evolution. Blackwell Scientific, London

Tifompson, G.-M., Al., J.-R., Song, X.-Y. \& JollEY, D.-W 2001. Fmeishan Basalts, SW China, reappraisal of the formation's type area stratigraphy and a discussion of its significance as a large igneosis province. format of the Geological Society, London, 158(4), 593.599.

Whaver, B. \& Takney, J. 1984. Impirical approach to estimating the composition of the continental crust. Natwe, 310, 575 .577.

WhITE, R.S. \& McKr:N7al;, I).P. 1995. Mantle plumes and continental bood basalts. foumal of Geophysical Researd, 100, 17.54 .317585

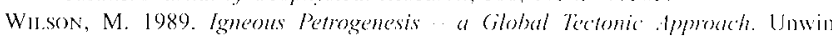
Hyman, London.

Xu, Y.-G., Chungi, S.1., IAHN, B.M. \& WU, (3.-Y. 2001. Petrologic and geochemical constraints on the petrogenesis of Permian Triassie Lmeishan llood basalts in southwestem (hina. Lithos, $58(3-4), 145168$

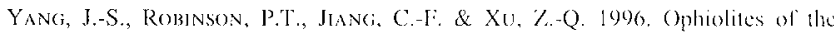
Kunlun Motntains, China and their tectonic implications, Tectonophastes. 258, 215-231.

Yin, A. \& Harrison, T.M. 2000. Geologie evolution of the llimaliayun Tibetan orogen. Ammal Reverw of Earth and Planetary Sciene's, 28, 211280.

YIN, A. \& NIF, S. 1993. An indentation model for North and South (diná collision and the development of the Tanlu and flonam fault system, eastem Asia. Tectomics, 12,801-813.

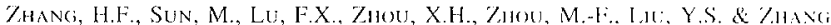
G.H. 2001. Geochemical significance of a garnet lherolite from the Dahongshan kimberlite, Yangtze Craton, southern (hna. feochemism Joumal. 35, 315 - 331.

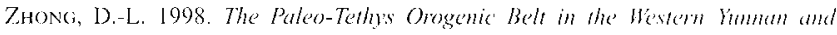
Sichuan, China. Scientific Publishing House, Beijing.

Zho1), D. \& Graham, S.A. 1996. The Songpan (ianri complex of the western Qinling Shan as a Triassic remnant ocean basin. In: YIN. A. \& IIAkRIston, T.M. (eds) The Tectonic Evolution of Asia. Cambridge University press. Cambridge, 281299

ZHot, M.-F., ҰHAO, T,-P., MAIPAS, J. \& SUN, M. 2000). Crustal-contaninated komatiitic basalts in southem (hina: products of Proterofoic mante plume underneath the Yangtae Block. Precambrian Research, 103. 175 189.

Zhou, M.-F., Mat.PAS, J. \& SoNG, X.-Y, RT M., 2002i. A tempolial link between the limeishan large igneous provine (SW (hina) and the end-(illadalupian mass extinction. Earth and Planetan Scitnce Letlers. 196, 113122

Zhou, M.-F., YAN, D.-P., KENNIIS, A.K., I.I. Y. \& DINC, J. 2002b. SIIRIMP U $\mathrm{Pb}$ zircon geochronological and geochemical evidence for Neoproteromoic arc-magnatism along the westem margin of the Yanglee Block, South (hina Earth and Planetary Science Letlers, 196, 5167 